\title{
Intranasal Corticosteroids in Management of Acute Sinusitis: A Systematic Review and Meta-Analysis
}

\author{
Gail Hayward, MBBChir, DPbil \\ Carl Heneghan, BM, BCH, MA, \\ MRCGP, DPbil \\ Rafael Perera, MSc, DPbil \\ Matthew Thompson, MBCbB, \\ $M P H, D P b i l, M R C G P$
}

Department of Primary Care Health Sciences, Oxford University, Oxford, England

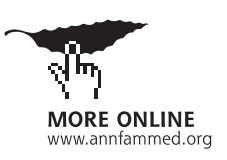

Conflicts of interest: authors report none.

\section{CORRESPONDING AUTHOR}

Gail Hayward, MBBChir, DPhil Department of Primary Care Health Sciences

2nd floor, 23-38 Hythe Bridge St Oxford, OX1 2ET United Kingdom gail.hayward@phc.ox.ac.uk

\begin{abstract}
PURPOSE Acute sinusitis is a common condition in ambulatory care, where it is frequently treated with antibiotics, despite little evidence of their benefit. Intranasal corticosteroids might relieve symptoms; however, evidence for this benefit is currently unclear. We performed a systematic review and meta-analysis of the effects of intranasal corticosteroids on the symptoms of acute sinusitis.
\end{abstract}

METHODS We searched MEDLINE, EMBASE, the Cochrane Central register of Controlled Trials (CENTRAL), and Centre for Reviews and Dissemination databases until February 2011 for studies comparing intranasal corticosteroids with placebo in children or adults having clinical symptoms and signs of acute sinusitis or rhinosinusitis in ambulatory settings. We excluded chronic/allergic sinusitis. Two authors independently extracted data and assessed the studies' methodologic quality.

RESULTS We included 6 studies having a total of 2,495 patients. In 5 studies, antibiotics were prescribed in addition to corticosteroids or placebo. Intranasal corticosteroids resulted in a significant, small increase in resolution of or improvement in symptoms at days 14 to 21 (risk difference $[R D]=0.08 ; 95 \% \mathrm{Cl}, 0.03$ 0.13 ). Analysis of individual symptom scores revealed most consistently significant benefits for facial pain and congestion. Subgroup analysis by time of reported outcomes showed a significant beneficial effect at 21 days $(\mathrm{RD}=0.11 ; 95 \% \mathrm{Cl}$, $0.06-0.17$ ), but not at 14 to 15 days ( $R D=0.05 ; 95 \%(l,-0.01$ to 0.11 ). Metaregression analysis of trials using different doses of mometasone furoate showed a significant dose-response relationship $(P=.02)$.

CONCLUSIONS Intranasal corticosteroids offer a small therapeutic benefit in acute sinusitis, which may be greater with high doses and with courses of 21 days' duration. Further trials are needed in antibiotic-naïve patients.

Ann Fam Med 2012;10:241-249. doi:10.1370/afm.1338

\section{INTRODUCTION}

cute sinusitis is a common condition, affecting an estimated 31 milA lion Americans annually. ${ }^{1}$ The majority of patients seen in primary that they provide limited benefit. ${ }^{4-6}$ The effectiveness of other treatments such as decongestants and antihistamines is largely unknown. ${ }^{7,8}$ Corticosteroids are effective in reducing symptoms in other upper respiratory tract infections such as croup, sore throat, and infectious mononucleosis, and their anti-inflammatory effects may be helpful for reducing sinus congestion and facilitating drainage in sinusitis. ${ }^{9-12}$

Currently, it is not clear whether corticosteroids offer significant benefits for patients with acute sinusitis. In particular, there have been no good-quality double-blind randomized controlled trials (RCTs) examining oral corticosteroids in acute sinusitis, even though the oral route is favored for other upper respiratory tract infections. In terms of intranasal steroids, 
a Cochrane review of 4 RCTs showed a small beneficial effect on improvement of symptoms at 15 to 21 days; however, interpretation was limited by both high heterogeneity and differing outcome measures used in the primary studies. ${ }^{13}$ A recent large RCT found no difference between intranasal corticosteroids and placebo for sinusitis. ${ }^{14}$ This trial was not included in the recent Cochrane review. ${ }^{13}$

Given the conflicting evidence, there is a pressing clinical need to clarify whether intranasal corticosteroids should be prescribed for patients with acute sinusitis. Accordingly, we undertook a systematic review of the most recent evidence to attempt to resolve this question.

\section{METHODS}

\section{Search Strategy and Selection}

We included in our meta-analysis RCTs that compared intranasal corticosteroids with placebo in children or adults who had clinical symptoms and signs of acute sinusitis or rhinosinusitis, in outpatient (ambulatory) settings. We excluded studies examining patients with chronic/allergic sinusitis and studies performed exclusively in patient populations selected because of chronic underlying health conditions (eg, immunocompromised patients).

We searched MEDLINE, EMBASE, the Cochrane Library including the Cochrane Central register of Controlled Trials (CENTRAL), the Database of Reviews of Effectiveness (DARE), and the National Health Service Health Economics Database from the beginning of each database until February 2011 using a maximally sensitive strategy. ${ }^{15}$ Medical Subject Heading (MeSH) terms used included rbinosinusitis, sinusitis, and corticosteroids (including dexametbasone, betamethasone, prednisone, and all variations of these terms) and viral and bacterial upper respiratory tract pathogens (full search strategy available from authors). Two authors independently reviewed the titles and abstracts of electronic searches, obtaining full-text articles to assess for relevance where necessary. Disagreements were resolved by discussion with a third author. We performed citation searches of all full-text papers retrieved.

\section{Data Extraction and Quality Assessment}

Two authors independently assessed the methodologic quality of studies. Quality was assessed using the criteria of allocation concealment, randomization, comparability of groups at baseline, blinding, treatment adherence, and percentage participation. Two authors independently extracted data using an extraction template. In both data extraction and quality assessment, disagreements were documented and resolved by discussion with a third author.

Primary outcomes included the proportion of participants with improvement or complete resolution of symptoms. Secondary outcomes included mean change in symptom scores over 0 to 21 days, adverse events, relapse rates, and days missed from school/ work. Where necessary, we used Grab It XP Microsoft Excel software (http://www.datatrendsoftware.com) to extract data from figures.

\section{Data Synthesis and Analysis}

For pooled analysis of dichotomous outcomes, we calculated the risk difference (RD), 95\% CI, and number needed to treat (NNT). For continuous variables, we used weighted mean difference and 95\% CIs. We tested dose response by undertaking a post hoc subgroup analysis according to intranasal corticosteroid dosage. We used meta-regression in Stata (StataCorp, LP) to test subgroup interactions on the outcomes and the $\mathrm{I}^{2}$ statistic to measure the proportion of statistical heterogeneity for each outcome. ${ }^{16}$ Where no heterogeneity was present, we performed a fixed-effect meta-analysis. Where substantial heterogeneity was detected, we looked for the direction of effect and considered the reasons for this heterogeneity. Where applicable, we used a random-effects analysis or considered not pooling the outcomes and reporting the reasons for this.

\section{RESULTS}

\section{Study Characteristics}

We identified 3,257 potentially relevant study records, of which 21 were relevant to acute sinusitis/rhinosinusitis (Figure 1). We excluded 15 of these studies for the following reasons: 5 were abstracts only with no full paper published or available from the authors, 3 were not limited to acute sinusitis, 3 examined oral steroids, 3 did not directly compare steroids and placebo, and 1 examined prevention of acute sinusitis.

The characteristics of included studies are presented in Table 1 . The 6 included studies randomized 2,495 patients recruited from outpatient otorhinolaryngology, emergency medicine, and general practice settings in 3 countries: the United States (4 studies), Turkey (1), and United Kingdom (1). The age range of participants varied: 12 years or older (3 studies); 16 years or older $(1) ; 18$ years or older $(1)$; and 15 years or younger (1). The corticosteroids used were budesonide (2 studies), fluticasone propionate (1), and mometasone furoate (3). Two trials compared 2 different doses of mometasone furoate. ${ }^{17,18}$

In addition to intranasal corticosteroids, 5 trials ${ }^{14,18-21}$ prescribed antibiotics (amoxicillin, co-amox- 
iclav, or cefuroxime) to patients in both groups. One of these trials ${ }^{19}$ prescribed intranasal xylometazoline hydrochloride to all participants before administration of the study spray for the first 3 days. Two trials reported outcomes based on computed tomography scans of sinuses. ${ }^{18,21}$

All 6 included studies demonstrated adequate allocation concealment, blinding, percentage participation, and comparability of groups both at baseline and in provision of care apart from the intervention; however, 3 studies did not report the method of randomization (Table 2). We therefore performed a sensitivity analysis excluding these studies.

\section{Resolution or Improvement of Symptoms at Days 14 to 21}

In $5 \mathrm{RCTs}^{14,17,18,20,21}$ that assessed resolution or improvement of symptoms at days 14 to 21, intranasal steroids had a modest clinical beneficial effect, with an RD of

\section{Figure 1. Flow diagram of search results.}

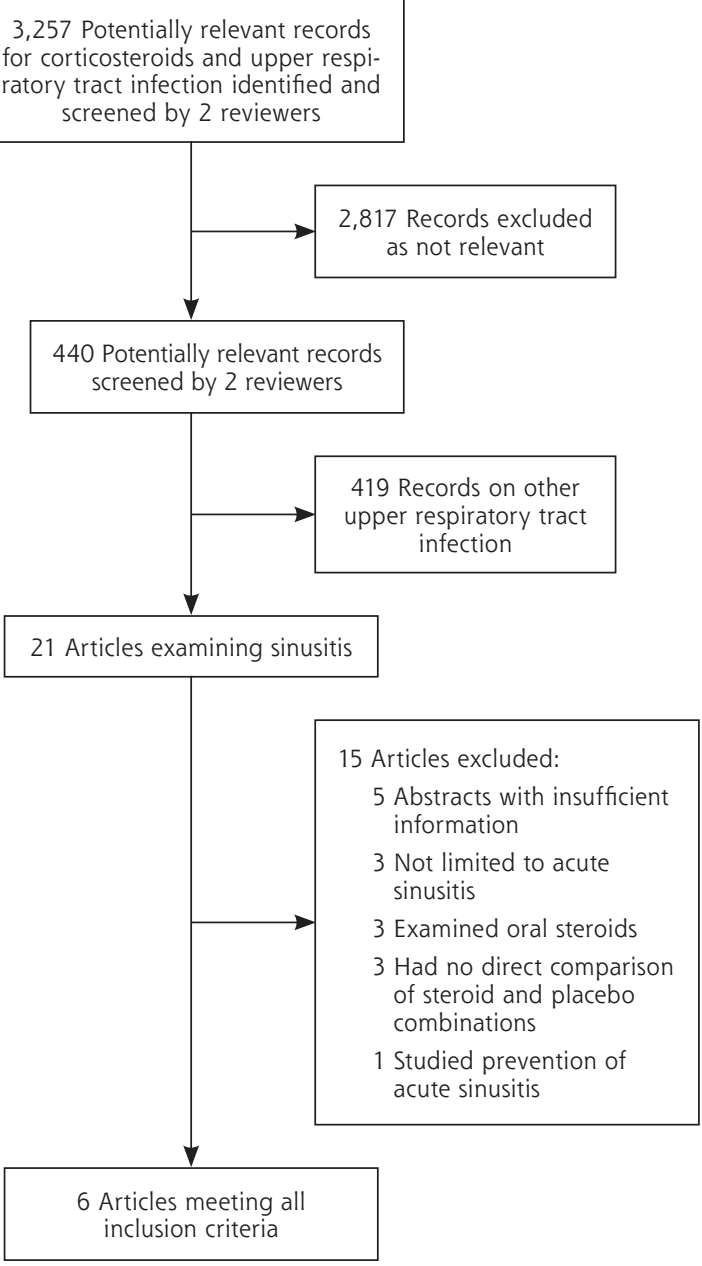

0.08 (95\% CI, $\left.0.03-0.13 ; P=.004 ; \mathrm{I}^{2}=47 \%\right)$ and an NNT of 13 (95\% CI, 8-33). This overall result was similar even with the removal of the 2 trials of lower quality ${ }_{1}^{18,21}$ with an RD of 0.07 (95\% CI, 0.01-0.12; $\left.P=.02 ; I^{2}=43 \%\right)$. Given that both analyses showed heterogeneity, however, we performed subgroup analyses on outcome timing and on dosage.

\section{Outcome Timing}

Combining the 3 studies reporting this outcome at 14 to 15 days s $^{14,17,20}$ showed no significant effect of intranasal corticosteroids, with an RD of 0.05 (95\% CI, -0.01 to $0.11 ; P=.13 ; I^{2}=22 \%$ ) (Figure $2 \mathrm{~A}$ ). In contrast, combining the 3 studies that reported resolution or improvement at 21 days $^{18,20,21}$ showed that intranasal corticosteroids had a significant beneficial effect with no heterogeneity, with an RD of 0.11 (95\% CI, 0.06$\left.0.17 ; P<.001 ; \mathrm{I}^{2}=0\right)$ and an NNT of $9(95 \% \mathrm{CI}, 6-17)$ (Figure 2B).

In the 2 trials $^{14,20}$ that reported the proportion of participants with persistent symptoms at 10 days after onset of treatment, there was no benefit of intranasal corticosteroids, with an RD of 0.06 (95\% CI, -0.09 to $\left.0.22 ; P=.41 ; I^{2}=47 \%\right)$. Two trials reported a small but significant $7 \%$ absolute improvement in physician evaluation scores at 21 days in patients receiving intranasal steroids vs placebo (Nayak et $\mathrm{al}^{18}$ : $61 \%$ vs $53 \%$, $P=.006$; Meltzer et $\mathrm{al}^{21}: 68 \%$ vs $\left.61 \%, P<.01\right)$.

\section{Dose-Dependent Benefit}

Three trials using mometasone furoate nasal spray $17,18,21$ showed a significant effect on symptom resolution or improvement at 15 to 21 days, with an RD of 0.08 (95\% CI, 0.01-0.14; $P=.02 ; \mathrm{I}^{2}=62 \%$ ) and an NNT of 13 (95\% CI, 7-100). The daily dose of mometasone furoate ranged in these 3 trials from $200 \mu \mathrm{g}$ to 800 $\mu \mathrm{g}$. We therefore investigated the high heterogeneity by performing subgroup analysis by dose. As depicted in Figure 3, meta-regression analysis of mometasone furoate dose and symptom resolution showed a significant dose-response relationship $(P=.02)$, with the effect size increasing with dose. For patients receiving $800 \mu \mathrm{g}$ of mometasone furoate nasal spray daily, the RD was $0.12(95 \% \mathrm{CI}, 0.06-0.18 ; P=.0002)$ and the NNT was 8 (95\% CI, 6-17); for those receiving $400 \mu \mathrm{g}$ daily, the RD was 0.07 (95\% CI, 0.03-0.11; $P=.001)$ and the NNT was 14 (95\% CI, 9-33).

\section{Individual Symptom Scores}

Three RCTs reported individual symptom scores in 5 groups of patients who received different doses of mometasone furoate compared with placebo ${ }^{17,18,21}$ For each group, the symptoms of facial pain, nasal congestion, headache, rhinorrhea, postnasal drip, and cough 


\section{Table 1. Characteristics of Trials Included in the Meta-Analysis}

\begin{tabular}{|c|c|c|c|c|}
\hline \multirow{2}{*}{$\begin{array}{l}\text { Study (Year and } \\
\text { Location) }\end{array}$} & \multirow{2}{*}{$\begin{array}{l}\text { Age Range } \\
\text { (Mean), y }\end{array}$} & \multicolumn{2}{|c|}{ No. Analyzed } & \multirow[b]{2}{*}{ Criteria for Sinusitis; Duration of Symptoms at Entry } \\
\hline & & Intervention & Control & \\
\hline \multirow{2}{*}{$\begin{array}{l}\text { Williamson et al }{ }^{14} \\
\text { (2007; United } \\
\text { Kingdom, general } \\
\text { practice) }\end{array}$} & $\geq 16(42.5)$ & $102^{a}$ & $105^{b}$ & $\begin{array}{l}2 \text { of following: predominantly unilateral purulent nasal discharge and } \\
\text { local pain, bilateral purulent nasal discharge, pus on inspection }\end{array}$ \\
\hline & & & & Median duration of symptoms 7 days (IQR 10) \\
\hline \multirow{2}{*}{$\begin{array}{l}\text { Meltzer et al }{ }^{17}(2005 \text {; } \\
14 \text { countries, medi- } \\
\text { cal centers) }\end{array}$} & $\geq 12(35.3)$ & 478 & 252 & $\begin{array}{l}\text { Symptoms score } \geq 5 / 15 \text { (scores of } 0=\text { none to } 3=\text { severe for facial pain, } \\
\text { nasal congestion, headache, rhinorrhea, and postnasal drip) }\end{array}$ \\
\hline & & & & Clinical signs/symptoms for $>7$ days but $<28$ days \\
\hline \multirow{3}{*}{$\begin{array}{l}\text { Nayak et al }{ }^{18}(2002 ; \\
\text { United States, } 61 \\
\text { treatment centers) }\end{array}$} & $\geq 12(39.1)$ & 642 & 325 & Coronal CT evidence of sinusitis \\
\hline & & & & $\begin{array}{l}\text { Total symptom score of } \geq 6 / 18 \text { (scores of } 0=\text { none to } 3=\text { severe for facial } \\
\text { pain, nasal congestion, headache, rhinorrhea, cough, and postnasal } \\
\text { drip) }\end{array}$ \\
\hline & & & & No information on duration given \\
\hline \multirow{3}{*}{$\begin{array}{l}\text { Dolor et al }{ }^{20}(2001 ; \\
\text { United States, } \\
12 \text { primary care and } \\
10 \text { otorhinolaryn- } \\
\text { gology clinics) }\end{array}$} & $\geq 18$ & 47 & 48 & History of recurrent sinusitis \\
\hline & & & & $\begin{array}{l}\text { Clinical criteria: } 2 / 5 \text { of headache; facial pain and pressure; nasal conges- } \\
\text { tion; purulent nasal discharge; and olfactory disturbance; and Water } \\
\text { radiographic or endoscopic evidence of sinusitis }\end{array}$ \\
\hline & & & & No information on duration given \\
\hline \multirow{3}{*}{$\begin{array}{l}\text { Meltzer et al } 21 \\
\text { (2000; United } \\
\text { States, } 29 \text { medical } \\
\text { centers, outpatient) }\end{array}$} & $\geq 12(40.4)$ & 200 & 207 & History of sinusitis episodes separated by symptom-free periods \\
\hline & & & & $\begin{array}{l}\text { Symptom score }>6 / 18 \text { (scores of } 0=\text { none to } 3=\text { severe on facial pain, } \\
\text { nasal congestion, headache, rhinorrhea, cough, and postnasal drip) } \\
\text { and coronal CT evidence of sinusitis }\end{array}$ \\
\hline & & & & Mean duration of symptoms 13.5 days \\
\hline \multirow[t]{2}{*}{$\begin{array}{l}\text { Barlan et al }{ }^{19}(1997 ; \\
\text { Turkey, pediatric } \\
\text { outpatient clinic) }\end{array}$} & $\leq 15(6.95)$ & 43 & 46 & $\begin{array}{l}\text { Clinical criteria: } 2 / 3 \text { of purulent nasal discharge, purulent pharyngeal } \\
\text { drainage, and cough, or } 1 / 3 \text { of the above plus } 2 \text { of facial or tooth pain, } \\
\text { edema, earache, sore throat, wheeze, headache, fever, and foul breath }\end{array}$ \\
\hline & & & & No information on duration given \\
\hline \multicolumn{5}{|c|}{$\mathrm{CT}=$ computed tomography; IQR = interquartile range; MFNS = mometasone furoate nasal spray; MSS = mean symptom score; SNOT-20 = 20-item Sino-Nasal Outcome Test. } \\
\hline \multicolumn{5}{|l|}{ a Total dose both nostrils. } \\
\hline \multicolumn{5}{|c|}{$\begin{array}{l}\text { b Factorial design means that each group included patients receiving both active and placebo antibiotics. } \\
\text { c Results of the } 2 \text { arms were combined for the overall analysis. }\end{array}$} \\
\hline
\end{tabular}

were reported on a scale of 0 (none) to 3 (severe) at baseline and averaged across the first 15 days of

therapy (see the Supplemental Appendix at http://

H www.annfammed.org/content/10/3/241/suppl/DC1 for full data). Compared with their counterparts who received placebo, patients who received intranasal corticosteroids in these 3 trials reported significantly greater improvement in facial pain (3 of the trials), con- gestion (3), rhinorrhea (2), headache (1), and postnasal drip (1) (all $P<.05)$.

\section{Adverse Events}

One trial reported that no adverse events occurred with steroid therapy ${ }^{19} ; 2$ trials reported no serious adverse events in either group ${ }^{14,20}$; and the remaining trials reported that adverse events were mainly mild or 


\begin{tabular}{|c|c|c|c|c|}
\hline \multicolumn{2}{|c|}{ Treatment } & \multirow{2}{*}{$\begin{array}{l}\text { Other Medications } \\
\text { Used }\end{array}$} & \multirow[b]{2}{*}{ Analgesia } & \multirow{2}{*}{$\begin{array}{l}\text { Outcomes and Definition of Symptom } \\
\text { Resolution }\end{array}$} \\
\hline Intervention $^{a}$ & Control & & & \\
\hline \multirow{4}{*}{$\begin{array}{l}400 \mu \mathrm{g} \text { budesonide } \\
\text { once daily for } 10 \\
\text { days }\end{array}$} & \multirow[t]{4}{*}{ Placebo spray } & \multirow{4}{*}{$\begin{array}{l}\text { Amoxicillin } 500 \text { mg } 3 \\
\text { times a day for } 7 \text { days } \\
\text { or placebo, factorial } \\
\text { design used }\end{array}$} & \multirow{4}{*}{$\begin{array}{l}\text { Not restricted, } \\
\text { not reported }\end{array}$} & Symptom scores assessed on 7-point scales \\
\hline & & & & Time to resolution of symptoms \\
\hline & & & & $\begin{array}{l}\text { Percent with complete resolution of symptoms up } \\
\text { to day } 14\end{array}$ \\
\hline & & & & $\begin{array}{l}\text { Resolution }=\text { patient reporting } 0 \text { or } 1 \text { on } 7 \text {-point } \\
\text { scale for } 11 \text { individual symptom scores }\end{array}$ \\
\hline 2 arms: ${ }^{c, d}$ & \multirow[t]{7}{*}{ Placebo spray } & \multirow[t]{7}{*}{$\begin{array}{l}\text { Separate study arm } \\
\text { received amoxicillin }\end{array}$} & \multirow[t]{7}{*}{ Prohibited } & $\begin{array}{l}\text { Major symptom score }=\text { sum of individual symp- } \\
\text { tom scores over days } 2-15 \text { of treatment }\end{array}$ \\
\hline daily or & & & & Time to onset of MSS being statistically different \\
\hline MFNS $200 \mu \mathrm{g}$ once & & & & from placebo \\
\hline in the morning & & & & Global response to treatment at day 15 \\
\hline $\begin{array}{l}\text { with placebo spray } \\
\text { in the evening }\end{array}$ & & & & Adverse events \\
\hline Each given for 15 days & & & & Recurrence \\
\hline & & & & Resolution = absence of failure of treatment \\
\hline 2 arms: $^{c}$ & \multirow[t]{5}{*}{ Placebo spray } & \multirow{5}{*}{$\begin{array}{l}\text { Amoxicillin-clavulanate } \\
\text { potassium } 875 \mathrm{mg} \text { twice } \\
\text { daily for } 21 \text { days }\end{array}$} & \multirow{5}{*}{$\begin{array}{l}\text { Not specifically } \\
\text { commented on; } \\
\text { not recorded }\end{array}$} & Change from baseline in total symptom score \\
\hline MFNS $200 \mu \mathrm{g}$ twice & & & & CT appearance of sinuses at 21 days \\
\hline daily or & & & & Percent of patients with resolution of symptoms \\
\hline $\begin{array}{l}\text { MFNS } 400 \mu \mathrm{g} \text { twice } \\
\text { daily }\end{array}$ & & & & Adverse events \\
\hline Each given for 21 days & & & & $\begin{array}{l}\text { Resolution }=\text { patient reporting complete or marked } \\
\text { relief of symptoms }\end{array}$ \\
\hline \multirow{9}{*}{$\begin{array}{l}400 \mu g \text { fluticasone } \\
\text { propionate once } \\
\text { daily for } 21 \text { days }\end{array}$} & \multirow[t]{9}{*}{ Placebo spray } & \multirow{9}{*}{$\begin{array}{l}\text { Cefuroxime axetil } 250 \mathrm{mg} \\
\text { twice daily for } 10 \text { days } \\
2 \text { puffs of xylometazoline } \\
\text { hydrochloride in each } \\
\text { nostril } 10 \text { min before } \\
\text { the study nasal spray for } \\
\text { the first } 3 \text { days }\end{array}$} & \multirow{9}{*}{$\begin{array}{l}\text { Allowed, } \\
\text { unregulated }\end{array}$} & Overall symptom score \\
\hline & & & & Percent of patients with resolution of symptoms \\
\hline & & & & Work attendance \\
\hline & & & & Work performance \\
\hline & & & & Quality of life (SNOT-20 score) \\
\hline & & & & Adverse events \\
\hline & & & & Recurrences \\
\hline & & & & Additional attendances \\
\hline & & & & $\begin{array}{l}\text { Resolution = patient report of symptoms much } \\
\text { improved or resolved }\end{array}$ \\
\hline \multirow[t]{5}{*}{$\begin{array}{l}\text { MFNS } 400 \mu \mathrm{g} \text { twice } \\
\text { daily for } 21 \text { days }\end{array}$} & \multirow[t]{5}{*}{ Placebo spray } & \multirow[t]{5}{*}{$\begin{array}{l}\text { Co-amoxiclav } 875 \mathrm{mg} \\
\text { twice daily for } 21 \text { days }\end{array}$} & \multirow{5}{*}{$\begin{array}{l}\text { Paracetamol only; } \\
\text { unregulated, } \\
\text { unrecorded }\end{array}$} & $\begin{array}{l}\text { Symptom scores assessed on 6-point scale (indi- } \\
\text { vidual symptoms and total scores) }\end{array}$ \\
\hline & & & & $\begin{array}{l}\text { Percent with complete resolution of symptoms at } \\
21 \text { days }\end{array}$ \\
\hline & & & & CT scoring of sinusitis (10-point scale) \\
\hline & & & & Adverse events \\
\hline & & & & $\begin{array}{l}\text { Resolution = patient reporting complete or marked } \\
\text { relief of symptoms }\end{array}$ \\
\hline \multirow{3}{*}{$\begin{array}{l}100 \mu \mathrm{g} \text { budesonide } \\
\text { twice daily for } 21 \\
\text { days }\end{array}$} & \multirow[t]{3}{*}{$\begin{array}{l}\text { Propellant- } \\
\text { only spray }\end{array}$} & \multirow{3}{*}{$\begin{array}{l}\text { Amoxicillin-clavulanate } \\
\text { potassium } 40 \mathrm{mg} / \mathrm{kg} \\
\text { daily for } 21 \text { days }\end{array}$} & \multirow[t]{3}{*}{ Not reported } & $\begin{array}{l}\text { Symptoms scores: median score of cough and } \\
\text { nasal discharge for first, second, and third weeks }\end{array}$ \\
\hline & & & & Relapse \\
\hline & & & & Resolution (no overall measure reported) \\
\hline
\end{tabular}

moderate in severity. ${ }^{17,18,21}$ Meta-analysis demonstrated no significant differences in the rate of overall adverse events between patients taking intranasal corticosteroids (299 of 1,299 , or $23 \%$ ) and placebo (181 of 797 , also $23 \%)(P=.83)$. Common adverse events were headache (noted in $2 \%-8 \%$ of patients, 4 studies), epistaxis $(3 \%-7 \%, 4$ studies), nasal irritation $(1 \%-2 \%$, 3 studies), and pharyngitis ( $2 \%-4 \%, 3$ studies). Meta- analysis of the rate of occurrence of these outcomes revealed no significant differences between steroid and placebo groups.

\section{Relapse and Recurrence}

Three trials ${ }^{17,19,20}$ reported the rate of relapse or recurrence of acute sinusitis up to 2 months after initiation of treatment. Recurrence occurred in $5 \%$ to $15 \%$ of 
Table 2. Methodologic Quality of Included Studies

\begin{tabular}{|c|c|c|c|c|c|c|}
\hline Study (Year) & $\begin{array}{l}\text { Allocation } \\
\text { Concealment }\end{array}$ & Randomization & $\begin{array}{l}\text { Comparability } \\
\text { of Groups at } \\
\text { Baseline }\end{array}$ & Blinding $^{a}$ & $\begin{array}{l}\text { Provision of } \\
\text { Care Apart } \\
\text { From the } \\
\text { Intervention }\end{array}$ & $\begin{array}{l}\text { Percentage } \\
\text { Participation }\end{array}$ \\
\hline $\begin{array}{l}\text { Williamson } \\
\text { et al }{ }^{14}(2007)\end{array}$ & Adequate & $\begin{array}{l}\text { Random number table, } \\
\text { block randomization }\end{array}$ & Comparable & Double blind & Equal & 86 \\
\hline $\begin{array}{l}\text { Meltzer et al }{ }^{17} \\
\quad(2005)\end{array}$ & Adequate & $\begin{array}{l}\text { Computer-generated ran- } \\
\text { domization stratified } \\
\text { by duration of symp- } \\
\text { toms at presentation }\end{array}$ & Comparable & Double blind & Equal & 90 \\
\hline $\begin{array}{l}\text { Nayak et al }{ }^{18} \\
(2002)\end{array}$ & $\begin{array}{l}\text { Adequate: matching } \\
\text { placebo used }\end{array}$ & $\begin{array}{l}\text { Randomized, method } \\
\text { not reported }\end{array}$ & Comparable & Double blind & Equal & 89 \\
\hline $\begin{array}{l}\text { Dolor et } \mathrm{al}^{20} \\
(2001)\end{array}$ & Adequate & $\begin{array}{l}\text { Permuted block random- } \\
\text { ization scheme strati- } \\
\text { fied by site }\end{array}$ & Comparable & Double blind & Equal & 94 \\
\hline $\begin{array}{l}\text { Meltzer et al }{ }^{21} \\
\quad(2000)\end{array}$ & $\begin{array}{l}\text { Adequate: matching } \\
\text { placebo used }\end{array}$ & $\begin{array}{l}\text { Randomized, method } \\
\text { not reported }\end{array}$ & Comparable & Double blind & Equal & 100 \\
\hline $\begin{array}{l}\text { Barlan et al }{ }^{19} \\
\text { (1997) }\end{array}$ & Adequate & $\begin{array}{l}\text { Randomized, method } \\
\text { not reported }\end{array}$ & Comparable & Double blind & Equal & 59 \\
\hline
\end{tabular}

Figure 2. Effect of intranasal steroids on resolution of symptoms of acute sinusitis at (A) 14 to 15 days and (B) 21 days.

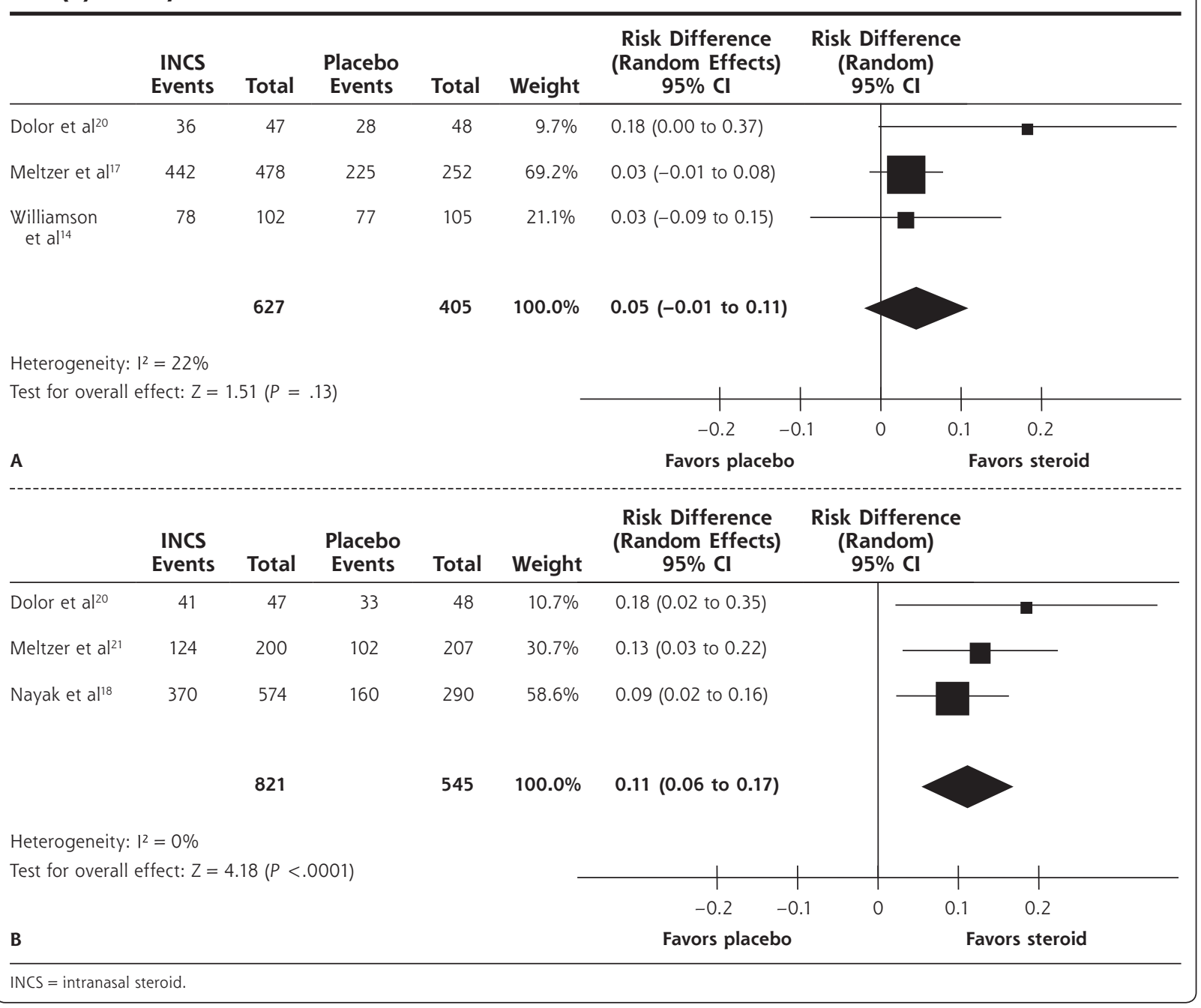




\section{Figure 3. Dose-response relationship of mometasone furoate and likelihood of symptom resolution.}

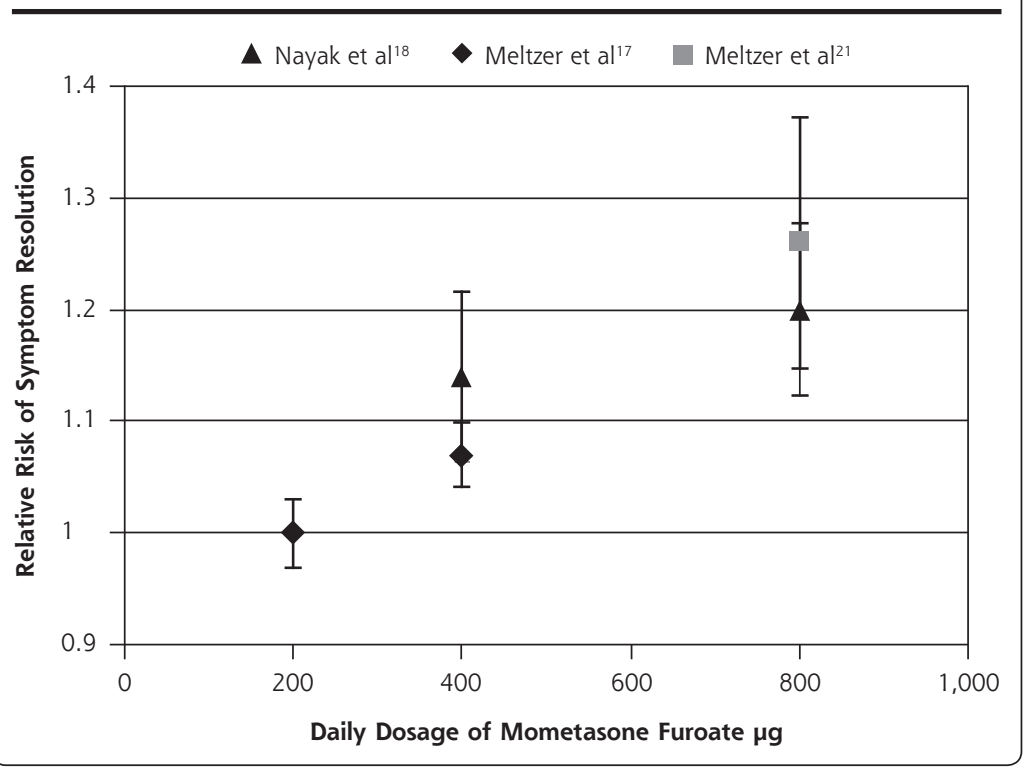

Only 1 included trial assessed the potential benefit of intranasal corticosteroids for work and quality of life outcomes in acute sinusitis. ${ }^{20}$ In this trial, the corticosteroid group had a significantly higher subjective level of work performance (median, 100\% vs $90 \%$ for placebo); however, there were no differences in work attendance or changes in quality of life as measured by the 20-item Sino-Nasal Outcome Test (SNOT-20) ${ }^{24}$ and the 12-Item Short Form Health Survey. ${ }^{25}$ An individual patient with acute sinusitis may therefore experience negligible adverse effects of intranasal corticosteroids in return for a small increase in likelihood of earlier resolution. This may be an acceptable trade-off for some patients. The therapeutic benefit at the population level is currently unclear. patients taking intranasal corticosteroids and $4 \%$ to $37 \%$ taking placebo.

\section{DISCUSSION}

\section{Key Findings}

This systematic review demonstrates that intranasal corticosteroids offer a small but significant symptomatic benefit in acute sinusitis. This effect is most marked when patients are given longer durations of treatment (21 days) and higher doses of the medication. Our analysis of individual symptom scores suggests that facial pain and nasal congestion may be most responsive to intranasal corticosteroids. In our main analysis, we found that whereas $66 \%$ of patients would experience improvement or resolution of symptoms at 14 to 21 days using placebo, an additional $7 \%$ of patients would achieve this outcome with corticosteroids, equating to an NNT of 13 .

This $7 \%$ gain is a relatively small increase in the context of a self-limiting condition, and this clinical benefit must be set against potential harms and economic implications. Our included trials reported no serious adverse events associated with intranasal corticosteroid use and no increase in frequency of nonserious adverse events compared with placebo. Other potential harms might include effects from systemic absorption; however, the single included trial addressing this outcome found no clinically relevant changes in the hypothalamicpituitary-adrenal axis, ${ }^{20}$ and 2 recent reviews found no evidence of suppression of this axis or of growth suppression with intranasal corticosteroids. ${ }^{22,23}$
Our subgroup analysis suggests the benefit of intranasal corticosteroids is most marked at 21 days, with an additional 11 patients experiencing symptom resolution for every 100 treated. In contrast, this effect was not significant at 15 days. Our subgroup analysis had only a small number of trials, however, and further research is needed to clarify the clinical benefit at 15 days or less (as discussed below). Clearly, patients are likely to experience pronounced symptoms in the first 7 to 14 days of their illness and may be less willing to consider a therapy that does not offer an increased likelihood of improvement in this earlier time period.

We found evidence of a dose-response relationship for mometasone furoate nasal spray: larger doses were associated with a greater likelihood of symptom resolution. We had insufficient data to assess whether other types of intranasal corticosteroids showed a similar effect, or whether this higher dose was associated with an increase in adverse events. On the basis of our review, when intranasal corticosteroids are used, we recommend doses of $800 \mu \mathrm{g}$ of mometasone furoate daily.

\section{Comparison With Existing Literature}

The small benefit of intranasal corticosteroids for the broad measure of symptom resolution or improvement at 14 to 21 days was similar in direction and size to that found in a recent Cochrane review. ${ }^{13}$ In both cases, however, marked heterogeneity was present. We have demonstrated that this heterogeneity arises from both the variation in the timing of the outcome measure and the dose of intranasal corticosteroids 
used. We found larger effect sizes in subgroup analyses by dose and timing of outcome measure. The recent Cochrane review may therefore have underestimated the benefit of intranasal corticosteroids. Williamson et $\mathrm{al}^{14}$ acknowledged that their RCT was underpowered to detect clinically useful effects, and the study may have used an inappropriately low dose of budesonide. ${ }^{26}$

\section{Limitations}

Important limitations of this systematic review include first, that 5 of the studies prescribed antibiotics to both steroid and placebo groups. Williamson et $\mathrm{al}^{14}$ found no interaction between antibiotic therapy and steroid therapy using a factorial design, which argues against a synergistic effect of these drug classes.

Second, included studies varied in the types and doses of steroids, duration of therapy, and outcome measures reported. Particularly, the definition of resolution of symptoms varied among the studies, and all measures of resolution involved subjective assessment. These factors prevented pooling of all outcomes and are likely to have contributed to the heterogeneity of the data.

Third, included studies were underpowered to detect rare adverse effects of corticosteroid, as well as relapse rates and days missed from work or school. Fourth, the limited number of trials meant we were unable to assess publication bias using funnel plots or place undue weight on the findings from small subgroup analyses. Finally, in 4 of the 6 included trials, radiologic or endoscopic evidence of acute sinusitis was an inclusion criterion. In ambulatory care, it is impractical and inappropriate to perform radiologic investigations on patients with symptoms of sinusitis.

\section{Recommendations for Research}

This review highlights the need for adequately powered RCTs comparing intranasal corticosteroids with placebo in the absence of antibiotics for symptom relief in acute sinusitis. We recommend that trials should use at least 21 days of therapy with high-dose mometasone furoate nasal spray. Inclusion criteria should be based on a clinical scoring system rather than radiologic evidence. Self-report and telephone follow-up should be used to assess the time to complete resolution of symptoms and also the time to onset of symptom resolution, which will be particularly important in clarifying whether there is benefit at time points earlier than 21 days. Recording the duration of symptoms at baseline will also improve our understanding of patterns of symptom resolution.

As acute sinusitis is diagnosed in an estimated 31 million Americans annually, ${ }^{1}$ a full assessment of economic implications is important. Such assessment should look at the cost of 21 days of therapy with high-dose mometasone furoate (equivalent to 3 bottles containing $140 \times 50-\mu \mathrm{g}$ doses) and the indirect cost savings in terms of attendance and performance at work or school and quality of life measures (eg, with the SNOT-20 score). ${ }^{24}$ These data will improve our understanding of whether the small benefit of this therapy for the individual has larger benefits at the population level. Antibiotics are widely prescribed for acute sinusitis despite limited evidence of beneficial effect; thus, measuring the extent to which intranasal corticosteroids reduce antibiotic prescribing will be highly relevant to clinical practice and policy. A systematic review using individual patient data may improve our ability to combine the data from existing research. Finally, a double-blind, placebo-controlled trial of the benefit of oral steroids in acute sinusitis has not yet been performed. Since delivery of intranasal corticosteroids to the nasal mucosa may be reduced by nasal congestion, and this may be a factor responsible for our finding of a nonsignificant benefit at 15 days, oral drug delivery might offer earlier and greater symptomatic relief.

In summary, on the basis of the current evidence, we believe that intranasal corticosteroids offer a small therapeutic benefit in acute sinusitis and may be most helpful for symptoms of facial pain and nasal congestion. This benefit may be greater with courses of 21 days in duration and with high-dose mometasone furoate. Future trials in antibiotic-naïve patients that clarify the time-course of clinical benefit and the impact on work and quality of life will be important to guide management of this common condition in family practice.

To read or post commentaries in response to this article, see it online at http://www.annfammed.org/content/10/3/241.

Key words: corticosteroids; sinusitis; meta-analysis; intranasal administration; inhaled; facial pain; congestion

Submitted April 20, 2011; submitted, revised, August 17, 2011; accepted September 6, 2011.

Funding support: Funding for this work was provided in part by a grant from the British Society for Antimicrobial Chemotherapy Systematic Review Grant (GA722SRG). The Department of Primary Health care is part of the National Institute of Health Research (NIHR) School of Primary Care Research.

Disclaimer: Neither the British Society for Antimicrobial Chemotherapy nor the National Institute of Health Research had any role in the design and conduct of the study; collection, management, analysis, and interpretation of the data; and preparation, review, or approval of the manuscript.

Acknowledgments: We would like to acknowledge the input of Professors Paul Glasziou and Chris Del Mar into the initial stages of this project. 


\section{References}

1. Lethbridge-Cejku M, Schiller JS, Bernadel L. Summary health statistics for U.S. adults: National Health Interview Survey, 2002. Vital Health Stat 10. 2004;Jul(222):1-151.

2. Ashworth M, Charlton J, Ballard K, Latinovic R, Gulliford M. Variations in antibiotic prescribing and consultation rates for acute respiratory infection in UK general practices 1995-2000. Br J Gen Pract. 2005;55(517):603-608.

3. Dosh SA, Hickner JM, Mainous AG III, Ebell MH; Upper Peninsula Research Network. Predictors of antibiotic prescribing for nonspecific upper respiratory infections, acute bronchitis, and acute sinusitis. An UPRNet study. J Fam Pract. 2000;49(5):407-414.

4. Ahovuo-Saloranta A, Borisenko OV, Kovanen N, et al. Antibiotics for acute maxillary sinusitis. Cochrane Database Syst Rev. 2008;(2): CD000243.

5. Rosenfeld RM, Singer M, Jones S. Systematic review of antimicrobial therapy in patients with acute rhinosinusitis. Otolaryngol Head Neck Surg. 2007;137(3 Suppl):S32-S45.

6. Young J, De Sutter A, Merenstein D, et al. Antibiotics for adults with clinically diagnosed acute rhinosinusitis: a meta-analysis of individual patient data. Lancet. 2008;371(9616):908-914.

7. Ah-See KW, Evans AS. Sinusitis and its management. BMJ. 2007;334 (7589):358-361.

8. Shaikh N, Wald ER, Pi M. Decongestants, antihistamines and nasal irrigation for acute sinusitis in children. Cochrane Database Syst Rev. 2010;(12):CD007909.

9. Low DE, Desrosiers M, McSherry J, et al. A practical guide for the diagnosis and treatment of acute sinusitis. CMAJ. 1997;156(Suppl 6): S1-S14.

10. Candy B, Hotopf M. Steroids for symptom control in infectious mononucleosis. Cochrane Database Syst Rev. 2006;3:CD004402.

11. Russell K, Wiebe N, Saenz A, et al. Glucocorticoids for croup. Cochrane Database Syst Rev. 2004;(1):CD001955.

12. Hayward G, Thompson M, Heneghan C, Perera R, Del Mar CB, Glasziou P. Corticosteroids for pain relief in sore throat: systematic review and meta-analysis. BMJ. 2009;339:b2976.

13. Zalmanovici A, Yaphe J. Intranasal steroids for acute sinusitis. Cochrane Database Syst Rev. 2009;(4):CD005149.

14. Williamson IG, Rumsby K, Benge $S$, et al. Antibiotics and topical nasal steroid for treatment of acute maxillary sinusitis: a randomized controlled trial [see comment]. JAMA. 2007;298(21)2487-2496.
15. Dickersin K, Manheimer E, Wieland S, Robinson KA, Lefebvre C, McDonald S. Development of the Cochrane Collaboration's CENTRAL Register of controlled clinical trials. Eval Health Prof. 2002;25(1):38-64.

16. Higgins JP, Thompson SG, Deeks JJ, Altman DG. Measuring inconsistency in meta-analyses. BMJ. 2003;327(7414):557-560.

17. Meltzer EO, Bachert C, Staudinger $H$. Treating acute rhinosinusitis: comparing efficacy and safety of mometasone furoate nasal spray, amoxicillin, and placebo. J Allergy Clin Immunol. 2005;116(6): 1289-1295.

18. Nayak AS, Settipane GA, Pedinoff A, et al; Nasonex Sinusitis Group. Effective dose range of mometasone furoate nasal spray in the treatment of acute rhinosinusitis. Ann Allergy Asthma Immunol. 2002;89(3):271-278.

19. Barlan IB, Erkan E, Bakir M, Berrak S, Başaran MM. Intranasal budesonide spray as an adjunct to oral antibiotic therapy for acute sinusitis in children. Ann Allergy Asthma Immunol. 1997;78(6):598-601.

20. Dolor RJ, Witsell DL, Hellkamp AS, Williams JW Jr, Califf RM, Simel DL; Ceftin and Flonase for Sinusitis (CAFFS) Investigators. Comparison of cefuroxime with or without intranasal fluticasone for the treatment of rhinosinusitis. The CAFFS Trial: a randomized controlled trial [see comment]. [Erratum appears in JAMA. 2004;292(14):1686]. JAMA. 2001;286(24):3097-3105.

21. Meltzer EO, Charous BL, Busse WW, Zinreich SJ, Lorber RR, Danzig MR; The Nasonex Sinusitis Group. Added relief in the treatment of acute recurrent sinusitis with adjunctive mometasone furoate nasal spray [see comment]. J Allergy Clin Immunol. 2000;106(4):630-637.

22. Demoly P. Safety of intranasal corticosteroids in acute rhinosinusitis. Am J Otolaryngol. 2008;29(6):403-413.

23. Derendorf H, Meltzer EO. Molecular and clinical pharmacology of intranasal corticosteroids: clinical and therapeutic implications. Allergy. 2008;63(10):1292-1300.

24. Piccirillo JF, Merritt MG Jr, Richards ML. Psychometric and clinimetric validity of the 20-Item Sino-Nasal Outcome Test (SNOT-20). Otolaryngol Head Neck Surg. 2002;126(1):41-47.

25. Ware JE Jr, Kosinski M, Keller SD. A 12-Item Short-Form Health Survey: construction of scales and preliminary tests of reliability and validity. Med Care. 1996;34(3):220-233.

26. Meltzer EO. Antibiotics and nasal steroids for acute sinusitis. JAMA. 2008;299(12):1422-1423, author reply 1423. 